\title{
THE INFLUENCE OF APPLICATION OF MODERNIZATION IN TAXATION ADMINISTRATION SYSTEM TOWARD \\ THE LEVEL OF TAX PAYER COMPLIANCE (Study of KPP Pratama Bantul Individual Tax Payers)
}

\author{
Aji Fauzie \\ Dewi Kusuma Wardani \\ ajifauzie@gmail.com \\ Program Studi Akuntansi, Fakultas Ekonomi \\ Universitas Sarjanawiyata Tamansiswa
}

\begin{abstract}
This study aimed to analyze the effect of the implementation of the modernization of the tax administration system of the level of compliance of individual taxpayers in the Tax Office Bantul Yogyakarta. This study uses judgment sampling and survey method with a questionnaire to collect data. Respondents were sampled in this study is the individual taxpayer listed on the Tax Office Bantul Yogyakarta. Analysis of research data using simple regression with SPSS 16.0

Based on the analysis of the individual results of hypothesis testing shows that the $t$ value for the modernization of the tax administration system variable $(X)$ on tax compliance ( $Y$ ) of 6.329 , mean $t$ count $>t$ table $(6.329>1.991)$, had a significance level of 0.000 for the level significance smaller than 0.05 , it means that this study shows the modernization of the tax administration system variables significant positive effect on tax compliance
\end{abstract}

Keywords : Modernization of the system of tax administration, tax compliance, tax administration

\section{PENDAHULUAN}

Untuk dapat mencapai tujuan utama pembangunan ekonomi, pendidikan, sosial budaya, pertahanan dan keamanan, pemerintah berusaha meningkatkan pendapatan nasional. Salah satu upaya pemerintah untuk mendapatkan dana untuk memenuhi segala bidang bidang tersebut, pemerintah menggali sumber dana yang berasal dari dalam negeri berupa pajak. Pajak merupakan kontribusi wajib kepada negara yang terutang olehorang pribadi atau badan yang bersifat memaksa berdasarkan Undang-Undang, dengan tidak mendapatkan imbalan secara langsung dan digunakan untuk keperluan negara bagi kemakmuran rakyat (UU No. 28 Tahun 2007).

Berbagai cara telah dilakukan oleh pemerintah untuk dapat meningkatkan sumber pendapatan dari pajak dan meningkatkan pelayanan terhadap wajib pajak, salah satunya adalah dengan mereformasi sistem perpajakan di Indonesia dari reformasi administrasi perpajakan sampai merubah serangkaian undangundang yang telah ada. Menurut Bawazier (2001) reformasi pajak di Indonesia dimulai tahun 1983 dengan memperkenalkan prinsip self assessment, menyederhanakan dan menurunkan tarif $\mathrm{PPh}$ dan memberlakukan PPN (Pajak Pertambahan Nilai) sebagai pengganti PPn (Pajak Penjualan). Menurut Suandy (2008) pemerintah telah beberapa kali melakukan reformasi perpajakan yaitu : reformasi pajak tahun 1983, reformasi pajak tahun 1994, dan reformasi pajak tahun 2000.

Tujuan utama reformasi perpajakan adalah untuk mendirikan kemandirian 
ekonomi dalam membiayai pembangunan nasional dengan jalan lebih mengerahkan kemampuan sendiri. Reformasi perpajakan akan menjadikan sistem yang berlaku menjadi lebih sederhana, yang mencakup penyederhanaan jenis pajak, tarif pajak, dan pembayaran pajak serta pembenahan aparatur perpajakan yang menyangkut prosedur, tata kerja, disiplin dan mental. Dengan reformasi pajak secara menyeluruh, diharapkan jumlah wajib pajak akan semakin meluas serta beban pajak akan semakin adil dan wajar, sehingga mendorong wajib pajak untuk melaksanakan kewajibannya dan menghindarkan diri dari aparat pajak yang mengambil keuntungan untuk kepentingan pribadi.

Menurut Fasmi dan Misra (2012) Konsep modernisasi administrasi perpajakan pada prinsipnya merupakan perubahan pada sistem administrasi perpajakan yang dapat mengubah pola pikir dan perilaku aparat serta tata nilai organisasi sehingga dapat menjadikan Direktorat Jenderal Pajak ( DJP ) menjadi suatu institusi yang profesional dengan citra yang baik di masyarakat. Program reformasi administrasi perpajakan diwujudkan dalam penerapan sistem administrasi perpajakan modern yang memiliki ciri khusus antara lain struktur organisasi yang dirancang berdasarkan fungsi, tidak lagi menurut seksi-seksi berdasarkan jenis pajak, serta perbaikan pelayanan bagi setiap wajib pajak melalui pembentukan account representative dan call center untuk menampung keluhan dan permasalahan Wajib Pajak. Sistem administrasi perpajakan modern juga mengikuti kemajuan teknologi dengan pelayanan yang berbasis $e$-system seperti $e$ SPT, e-billing, dan e-Registration yang diharapkan meningkatkan mekanisme kontrol yang lebih efektif yang ditunjang dengan penerapan kode etik Pegawai Direktorat Jenderal Pajak (DJP) yang mengatur perilaku pegawai dalam melaksanakan tugas (Rahayu dan Sri 2009).

Modernisasi sistem administrasi perpajakan yang dicanangkan Direktorat Jenderal Pajak, tentunya bukan tanggung jawab Direktorat Jenderal Pajak semata. Keberhasilan modernisasi sistem administrasi perpajakan membutuhkan kerja sama dan keterbukaan hati dari kedua belah pihak, baik dari Direktorat Jenderal Pajak maupun Wajib Pajak. Karena itu, Direktorat Jenderal Pajak mengharapkan apa yang diprogramkan oleh Direktorat Jenderal Pajak melalui modernisasi sistem administrasi perpajakan mampu menggugah hati semua pihak ikut larut dan ikut dalam mewujudkannya. Adanya modernisasi sistem administrasi perpajakan ini juga diharapkan mampu meningkatkan kepuasan Wajib Pajak. Tingkat kepuasan dan Wajib Pajak ini dapat tercermin dalam ketepatan waktu dalam menyampaikan SPT karena kemudahan $e$-SPT, berkurangnya denda atas keterlambatan pembayaran angsuran pajak karena kesulitan pengisian formulir, dan akhirnya kepuasan Wajib Pajak akan berimplikasi pada meningkatnya kepatuhan membayar pajak.

Dengan substansi yang dikembangkan terbatas pada penerapan sistem administrasi perpajakan modern sebagai praktek reformasi administrasi perpajakan, peneltian ini dimaksudkan untuk mengetahui pengaruh sistem administrasi perpajakan modern dalam kerangka reformasi administrasi sistem perpajakan jangka menengah yang diigulirkan Direktorat Jenderal Pajak Kantor Pelayanan Pajak (KPP) Pratama Bantul terhadap kepatuhan wajib pajak, maka dalam penelitian ini penulis mengambil judul

\section{Pengaruh Penerapan Modernisasi} Sistem Administrasi Perpajakan Terhadap Tingkat Kepatuhan Wajib Pajak (Studi Empiris di Kantor Pelayanan Pajak PratamaBantul Yogyakarta)

\section{LANDASAN TEORI Konsep dan Sistem Perpajakan Indonesia}

Siahaan (2010) menyampaikan bahwa pemungutan pajak di Indonesia memiliki corak dan ciri tersendiri yang berbeda dengan negara lain dan menunjukan pajak sebagai wujud kewajiban kenegaraan 
setiap anggota masyarakat ciri dan corak pemungutan pajak Indonesia yaitu :

a. Pemungutan pajak merupakan perwujudan dari pengabdian dan peran serta wajib pajak untuk secara langsung dan bersama sama melaksana kan kewajiban yang diperlukan untuk pembiayaan penyelengaraan negara dan pembangunan nasional

b. Tanggung jawab atas pelaksanaan pemungutan pajak sebagai pencerminan di bidang perpajakan berada pada anggota masyarakat/wajib pajak sendiri

c. Anggota masyarakat / wajib pajak diberi kepercayaan untuk melaksanakan kegotong royongan nasional melalui sistem menghitung, memperhitungkan, membayar, dan melaporkan sendiri pajak yang terutang (self assesment), sehinggan melalui sistem ini administrasi perpajakan diharapkan dapat dilaksanakan lebih rapi, terkendali, sederhana, dan mudah dipahami oleh anggota masyarakat/wajib pajak.

Sistem perpajakan Indonesia ini mempunyai arti bahwa penentuan penetapan besarnya pajak terutang dipercayakan kepada wajib pajak sendiri untuk melaporkan secara teratur jumlah yang terutang dan yang telah dbayar sebagaimana dietentukan dalam peraturan perundang - undangan perpajakan. Aparat perpajakan berperan aktif dalam melaksanakan pengendalian administrasi pemungutan pajak yang meliputi tugastugas pembinaan, pelayanan, pengawasan, dan penerapan sanksi perpajakan. Pembinaan masyarakat/ wajib pajak dilakukan memlalui berbagai upaya, antara lain pemberian penyuluhan perpajakan, baik melalui media massa maupun penerangan langsung kepada masyarakat

\section{Definisi Pajak}

Menurut UU No. 28 Tahun 2007 Pajak merupakan kontribusi wajib kepada negara yang terutang oleh orang pribadi atau badan yang bersifat memaksa berdasarkan UndangUndang, dengan tidak mendapatkan imbalan secara langsung dan digunakan untuk keperluan negara bagi sebesar-besarnya kemakmuran rakyat. Definisi pajak menurut Soemitro (1994) guru besar dalam Hukum Pajak pada Universitas Padjajaran, Bandung,

iuran rakyat kepada kas negara(peralihan kekayaan dari sektor partikulir ke sektor pemerintah) berdasarkan undang-undang (dapat dipaksakan) dengan tiada mendapat jasa timbal (tegenprestasi), yang langsung dapat ditunjukkan dan digunakan untuk membiayai pengeluaran umum.

\section{Subyek Pajak}

Menurut Suandy (2008) Secara umum pengertian subyek pajak atau wajib pajak adalah siapa yang dikenakan pajak. Secara praktik yang termasuk dalam pengertian subyek pajak meliputi orang pribadi, warisan yang belum terbagi sebagai kesatuan, badan,dan bentuk usaha tetap

\section{Reformasi Administrasi Perpajakan}

Nasucha (2004) menambahkan bahwa reformasi administrasi perpajakan dapat dilaksanakan tanpa melakukan reformasi perpajakan, yaitu untuk mensinergikan faktor internal dan eksternal yang mempengaruhi kinerja organisasi. Lingkungan eksternal yang dimaksud adalah kebijakan fiskal, antara lain item-item yang tidak dimasukkan dalam dasar pengenaan pajak, pembelanjaan dan pelayanan publik.

Dalam ekonomi yang mulai berkembang, administrasi perpajakan harus difokuskan kepada wajib pajak besar secara maksimal dan memberikan kontribusi kepada wajib pajak kecil. Dengan mendasarkan pada teori Caiden (1991), menurut Nasucha (2004), empat dimensi reformasi administrasi perpajakan, yaitu:

1) Struktur organisasi.

Mengutip Adiwisatra (1998), dalam Nasucha (2004) bahwa struktur organisasi adalah unsur yang berkaitan dengan polapola peran yang sudahditentukan dan hubungan antar peran, alokasi kegiatan kepada sub unit-subunit terpisah, pendistribusian wewenang diantara posisi 
administratif, dan jaringan komunikasi formal.

2) Prosedur organisasi.

Prosedur organisasi berkaitan dengan proses komunikasi, pengambilan keputusan, pemilihan prestasi, sosialisasi dan karier. Pembahasan dan pemahaman prosedur organisasi berpijak pada aktivitas organisasi yang dilakukan secara teratur.

3) Strategi organisasi.

Strategi organisasi dipandang sebagai siasat, sikap pandangan dan tindakan yang bertujuan memanfaatkan segala keadaan, faktor, peluang, dan sumber daya yang ada sedemikian rupa sehingga tujuan organisasi dapat dicapai dengan berhasil dan selamat. Strategi berkembang dari waktu ke waktu sebagai pola arus keputusan yang bermakna.

4) Budaya organisasi.

Budaya organisasi didefinisikan sebagai sistem penyebaran kepercayaan dan nilai-nilai yang berkembang dalam organisasi dan mengarahkan perilaku anggota-anggotanya. Budaya organisasi mewakili persepsi umum yang dimiliki oleh anggota organisasi.

Adapun tujuan modernisasi perpajakan adalah menurut Nasucha (2004) yaitu untuk menjawab latar belakang dilakukannya modernisasi perpajakan, yaitu:

1. Tercapainya tingkat kepatuhan pajak (tax compliance) yang tinggi.

2. Tercapainya tingkat kepercayaan (trust) terhadap administrasi perpajakan yang tinggi.

3. Tercapainya tingkat produktivitas pegawai pajak yang tinggi

\section{Kepatuhan Wajib Pajak}

Kepatuhan wajib pajak dalam melaksanakan kewajiban pajaknya menurutUndang-Undang Republik Indonesia Nomor 28 Tahun 2007 Tentang Ketentuan Umum Dan Tata Cara Perpajakan pasal 17 C ayat 2 didasarkan pada kriteria sebagai berikut :

1. Tepat waktu dalam menyampaikan Surat Pemberitahuan

2. Tidak mempunyai tunggakan pajak untuk semua jenis pajak, kecuali tunggakan pajak yang telah memperoleh izin untuk mengangsur atau menunda pembayaran pajak.

3. Laporan Keuangan diaudit oleh Akuntan Publik atau lembaga pengawasan keuangan pemerintah dengan pendapat Wajar Tanpa Pengecualian selama 3 (tiga) tahun berturut-turut, atau dengan pendapat wajar dengan pengecualian, sepanjang pengecualian tersebut tidak mempengaruhi laba rugi fiskal. Selanjutnya ditegaskan bahwa seandainya laporan keuangan diaudit, laporan audit tersebut harus disusun dalam bentuk panjang (long form report) dan menyajikan rekonsiliasi laba rugi komersial dan fiskal, dan

4. Tidak pernah dipidana karena melakukan tindak pidana di bidangperpajakan berdasarkan putusan pengadilan yang telah mempunyaikekuatan hukum tetap dalam jangka waktu 5 (lima) tahun terakhir.

Menurut Nurmantu (2005), ada beberapa faktor yang menentukan tinggi rendahnya kepatuhan perpajakan, antara lain kejelasan (clatiry) undang-undang dan peraturan pelaksanaan perpajakan, besarnya biaya kepatuhan (compliance cost) dan adanya panutan.

\section{METODOLOGI PENELITIAN Sifat Penelitian}

Metode penelitian yang digunakan pada penelitian ini adalah metode penelitian kuantitatif. Metode penelitian kuantitatif adalah Penelitian menggunakan metode eksperimental untuk menguji hipotesis dengan tujuan menemukan generalisasi dan menekankan pada pengukuran dan analisis hubungan sebab akibat diantara variabel Sekaran (2006).

\section{Variabel Penelitan}

Penelitian ini melibatkan dua variabel yang terdiri atas satu variabel independen dan satu variabel dependen. Variabel dependen merupakan varabel terikat atau 
variabel yang dijelaskan dan dipengaruhi oleh variabel independen Varibel dependen dalam penelitian ini adalah kepatuhan perpajakan.

Variabel independen adalah variabel bebas atau variabel yang mempengaruhi variabel lain. Variabel independen dalam penelitian ini adalah variabel penerapan sistem adminitrasi perpajakan modern yang dikembangkaan dalam variabel reformasi administrasi perpajakan menurut Nasucha ( 2004 ) yang memuat dimensi modernisasi struktur organisasi, modernisasi prosedur organisasi, modernisasi strategi organisasi, dan modernisasi budaya organisasi.

\section{Populasi dan Sampel \\ Populasi}

Menurut Husein (2005) dalam Aprilina (2013) populasi sebagai wilayah generalisasi yang terdiri atas obyek atau subyek yang mempunyai kesempatan yang sama untuk dipilih menjadi sampel. Menurut Sekaran (2006) dalam Aprilina (2013) populasi (population) mengacu pada keseluruhan kelompok orang, kejadian, atau hal minat yang ingin peneliti investigasi Populasi dalam penelitian ini adalah wajib pajak orang pribadi (WPOP) yang terdaftar di kantor pelayanan pajak ( KPP ) Pratama Bantul. Tidak semua wajib pajak orang pribadi yang terdafar di KPP Pratama Bantul menjadi obyek dalam penelitian ini dikarenakan jumlahnya sangat besar.Peneliti memiliki asumsi bahwa Objek yang diteliti merupakan Wajib Pajak yang mengerti tentang sistem modernisasi administrasi perpajakan

Pengambilan sampel dalam penelitian ini menggunakan metoda judgement sampling atau purposive sampling. Metoda judgement sampling yaitu suatu metode yang melibatkanpilihan-pilihan dari subyek yang memiliki tempat paling menguntungkan atau posisi terbaik yang menyediakan informasi yang dibutuhkan (Sekaran, 2006). Jogiyanto (2008)

Dalam penelitian ini responden yang menjadi sampel adalah wajib pajak orang pribadi yang termasuk populasi penelitian dan kebetulandijumpai di kantor pelayanan pajak (KPP) Pratama Bantul. Sampel yang digunakan dalam penelitian ini adalah wajib pajak orang pribadi yang terdaftar di Kantor Pelayanan Pajak Pratama Bantul Yogyakarta. Sampel diperoleh dari kuesioner yang disebar sebanyak 100 kuesioner. Kuesioner tersebut pertama disebar di Kantor Pelayanan Pajak Pratama Bantul Yogyakarta pada tanggal 20 September 2013, yang kedua pada tanggal 24 september 2013 dan yang terakhir pada tanggal 01 Oktober 2013 dari 100 kuesioner hanya 80 kuesioner yang digunakan, 10 kuesioner tidak dikembalikan, 5 kuesioner tidak terisi penuh, 5 kuesioner terdapat pengisian ganda .

\section{Jenis dan Sumber Data}

Jenis data yang digunakan dalam penelitian ini merupakan data primer berupa kuesioner yang diisi oleh responden. Sumber data primer pada penelitian ini diperoleh secara langsung dari para wajib pajak orang pribadi yang terdaftar di KPP Pratama Bantul. Kuesioner ini berisi pertanyaan bersifat tertutup. Kuesioner ini terdiri dari dua bagian yaitu bagian pertama berisi tentang pertanyaan-pertanyaan yang bersifat umum untuk mendapatkan data tentang responden, dan bagian kedua berisi pertanyaan-pertanyaan yang berhubungan dengan variabel-variabel dalam penelitian yang digunakan untuk mendapatkan data penelitian.

\section{Metode Pengumpulan Data}

Metode pengumpulan data dalam penelitian ini dilakukan dengan menggunakan metode angket (kuesioner). Kuesioner adalah daftar pertanyaan yang harus dijawab dan atau daftar isian yang harus diisi oleh responden. Sejumlah pertanyaan diajukan dalam bentuk kuesioner dan kemudian responden diminta menjawab sesuai dengan pendapat mereka. Untuk mengukur pendapat responden digunakan skala lima angka yaitu angka 5 untuk pendapat sangat setuju (SS) dan angka 1 untuk sangat tidak setuju (STS). 


\section{Metode Analisis Data}

Alat analisis yang digunakan dalam penelitian ini adalah analisis regresi. Beberap langkah yang dilakukan dalam analisis regresi adalah sebagai berikut

\section{Statistik Deskriptif}

Statistik deskriptif digunakan untuk memberikan penjelasan gambaran demografi responden penelitian dan deskripsi mengenai variabel-variabel penelitian untuk mengetahui distribusi frekuensi absolut yang menunjukkan minimal, maksimal, rata-rata (mean), median, dan penyimpangan baku (standar deviasi) dari masing-masing variabel penelitian.

\section{Uji Validitas dan Realibilitas}

Untuk menguji apakah konstruk yang telah dirumuskan reliabel dan valid maka, perlu dilakukan pengujian validitas dan reliablitas. uji validitas dilakukan dengan tujuan untuk mengetahui kesahihan kuesioner. Suatu angket (kuesioner) dikatakan valid apabila angket mampu mengukur apa yang seharusnya diukur (Ghozali, 2011). Selanjutnya untuk mengetahui apakah suatu item valid atau gugur maka dilakukan perbandingan antara koefisien $r$ hitung dengan koefisien $r$ tabel. Jika $r$ hitung $>r$ tabel berarti item valid. Sebaliknya jika $r$ hitung < dari $r$ tabel berarti item tidak valid (gugur).

\section{Uji Asumsi Klasik}

\section{Koefisien Determinasi $\left(\mathbf{R}^{2}\right)$}

Koefisien determinasi digunakan untuk mengukur seberapa jauh kemampuan model dalam menerangkan variasi variabel dependen. Nilai koefisien determinasi adalah diantara nol sampai satu (Ghozali, 2006). Nilai $R^{2}$ yang kecil berarti kemampuan variabel-variabel independen dalam menjelaskan variasi variabel dependen amat terbatas.

\section{Uji t}

Uji $t$ dilakukan untuk mengetahui seberapa jauh pengaruh satu variabel independen secara individual dalam menerangkan variasi variabel dependen. Kriteria pengujian yang digunakan adalah jika t-hitung > t-tabel dengan tingkat signifikansi 0,05 maka H0 ditolak (Ghozali, 2006).

\section{Model Regresi}

Dalam penlitian ini model regresi yang digunakan adalah regresi sederhana, Yaitu alat analisis untuk mengetahui ketergantungan variabel dependen (terikat) dengan satu atau lebih variabel independen (variabel penjelas) dengan tujuan untuk mengestimasi atau memprediksi rata-rata populasi atau nilai rata-rata variabel dependen berdasarkan nilai variabel independen yang diketahui (Gujarati, 2003) dalam Ghozali (2011). Karena teknik analisis data pada penelitian ini menggunakan regresi sederhana maka dapat dituliskan persamaan regresinya sebagai berikut :

$\mathbf{Y}=\mathbf{a}+\mathbf{b} 1 \mathbf{X} 1+e$

Keterangan :

Y : kepatuhan Wajib Pajak

a : nilai intersep (konstan)

b1 : koefisien arah regresi

X1 : variabel modernisasi sistem

administrasi perpajakan

$e \quad:$ error

\section{ANALISIS DAN PEMBAHASAN Statistik Derskriptif}

Diketahui bahwa 100 kuesioner yang disebar yang dikembalikan sebanyak 80 buah, yang tidak terisi lengkap sebanyak 5 buah, yang tidak dikembalikan sebanyak 20 buah dan pengisian ganda sebanyak 5 buah sehingga jumlah 80 kuesioner telah memenuhi syarat penelitian, sebab telah memenuhi syarat sampel. 


\section{Hasil Uji Kualitas Data}

a. Hasil Uji Realibilitas

\section{Tabel 1}

Uji Realibilitas

\begin{tabular}{lcc}
\hline \multicolumn{1}{c}{ Variabel } & Nilai Cronbach alpha & Keterangan \\
\hline $\begin{array}{l}\text { Modernisasi Sistem } \\
\begin{array}{l}\text { Administasi Perpajakan } \\
(\mathrm{X})\end{array}\end{array}$ & 0.742 & Realibel \\
$\begin{array}{l}\text { Kepatuhan Wajib Pajak } \\
(\mathrm{Y})\end{array}$ & 0.770 & \\
\hline
\end{tabular}

Sumber : Data Primer yang diolah, 2013

b. Hasil Uji Validitas

Tabel 2

Uji Validitas Variabel X

\begin{tabular}{ccc}
\hline TbKuesioner X & Korelasi Pearson & Keterangan \\
\hline Item 1 & 0.678 & valid \\
Item 2 & 0.672 & Valid \\
Item 3 & 0.738 & valid \\
Item 4 & 0.710 & Valid \\
Item 5 & 0.514 & Valid \\
Item 6 & 0.641 & Valid \\
Item 7 & 0.624 & Valid \\
Item 8 & 0.424 & Valid \\
Item 9 & 0.516 & Valid \\
Item 10 & 0.409 & valid \\
Item 11 & 0.414 & Valid \\
Item 12 & 0.477 & Valid
\end{tabular}

Sumber : Data primer yang diolah,

Tabel 3

Uji Validitas Variabel Y

\begin{tabular}{ccc}
\hline Kuesioner Y & Korelasi Pearson & Keterangan \\
\hline Item 13 & 0.658 & Valid \\
Item 14 & 0.758 & Valid \\
Item 15 & 0.663 & Valid \\
Item 16 & 0.728 & Valid \\
Item 17 & 0.628 & Valid \\
Item 18 & 0.708 & Valid \\
Item 19 & 0.730 & Valid \\
\hline
\end{tabular}

Sumber : Data Primer yang diolah, 2013 


\section{Hasil Uji Asumsi Klasik}

1. Uji Normalitas

Uji Normaltas adalah pengujian tentang kenormalan distribusi data. Penggunaan normalitas karena pada analisis statistik, asumsi yang harus dimiliki oleh data adalah bahwa data tersebut terdistribusi normal (Santosa dan Ashari, 2005). Uji normalitas data dilakukan untuk melihat bahwa suatu dataterdistribusi secara normal atau tidak. Uji normalitas data dilakukan dengan menggunakan bentuk grafik distribusi.

\section{Gambar 1}

\section{Grafik Distribusi}

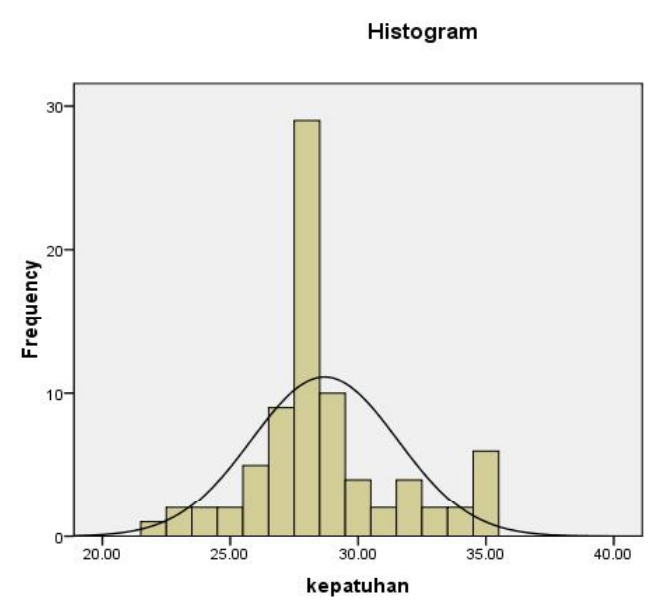

$\begin{aligned} \text { Mean } & =28.69 \\ \text { Std. Dev } & =2.87 \\ N & =80\end{aligned}$

Dari hasil tersebut terlihat bahwa grafik kepatuhan memperlihatkan hasil bahwa bentuk grafik kepatuhan mengikuti bentuk grafik ditribusi normal. Dari grafik tersebut terlihat bahwa bentuk grafik distribusi cenderung miring ke kanan, lebih runcing.

\section{Uji Heteroskidastisitas}

Salah satu asumsi dalam regresi berganda adalah uji Heteroksidasitas. Asumsi Heteroksidastisitas adalah asumsi dalam regresi dimana varians dari residual tidak sama untuk satu pengamatan ke pengamatan lain. Dalam regresi, salah satu asumsi yang harus dipenuhi adalah bahwa varians dari residual satu pengamatan ke pengamtan yang lain tidak memiliki pola tertentu. Model regresi yang baik adalah yang Homoskesdatisitas atau tidak terjadi heteroskedastisitas. Hasil pengujian heteroskedastisistas yang terlihat pada grafik scatterplot tidak membentuk suatu pola tertentu. Kesimpulannya, regresi terbebas dari heteroskedastisitas. Artinya, seluruh variabel-variabel yang mempengaruhi persamaan regresi dapat diketahui secara pasti.

\section{Gambar 2 \\ Uji Heteroskidastisitas}

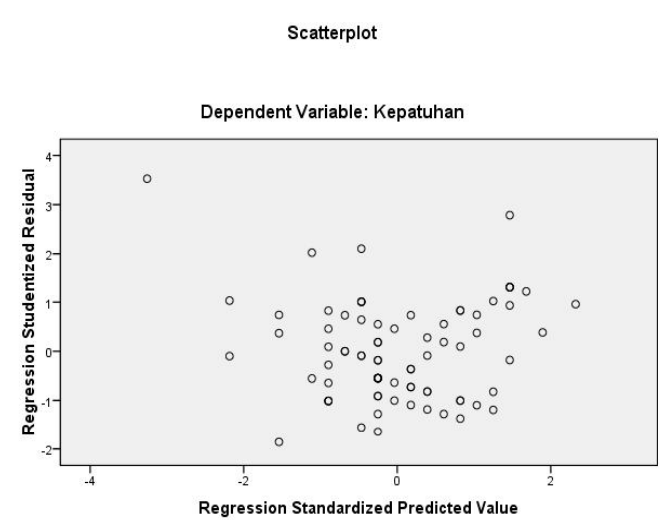

\section{Hasil Analisis Regresi Sederhana}

Analisis Regresi Sederhana yaitu alat analisis untuk mengetahui ketergantungan variabel dependen (terikat) dengan satu atau lebih variabel independen (variabel penjelas) dengan tujuan untuk mengestimasi atau memprediksi rata-rata populasi atau nilai rata-rata variabel dependen berdasarkan nilai variabel independen yang diketahui (Gujarati, 2003) dalam Ghozali (2011).

Tabel 4

Uji Regresi Sederhana

\begin{tabular}{llrrrrr}
\hline Model & & \multicolumn{2}{c}{ Standardized } & & \multicolumn{2}{c}{ Sig. } \\
\hline 1 & (Constant) & 30.788 & 4.864 & & 6.329 & .000 \\
& Modernisasi & .641 & .169 & .395 & 3.799 & .000 \\
\hline
\end{tabular}




\begin{tabular}{|c|c|c|c|c|c|c|}
\hline \multirow{2}{*}{$\frac{\text { Model }}{1}$} & \multirow[b]{2}{*}{ (Constant) } & \multicolumn{2}{|c|}{ Unstandardized Coefficients } & \multirow[t]{2}{*}{$\begin{array}{c}\text { Standardized } \\
\text { Coefficients }\end{array}$} & \multirow{2}{*}{$\frac{\mathrm{t}}{6.329}$} & \multirow[t]{2}{*}{ Sig. } \\
\hline & & 30.788 & 4.864 & & & \\
\hline & Modernisasi & .641 & .169 & .395 & 3.799 & .000 \\
\hline
\end{tabular}

a. Dependent Variable: Kepatuhan

Berdasarkan Tabel tersebut, maka dapat ditulis persamaan regresi sebagai berikut : $Y=30.788+0,641 X+e$

Konstanta (alpha) sebesar 30.788 memberi pengertian modernisasi sistem administrasi perpajakanpada Kantor Pelayanan Pajak Pratama Bantul Yogyakarta tidak ada atau sama dengan nol (0), maka besarnyatingkat kepatuhan pajak wajib pajak orang pribadi pada Kantor Pelayanan Pajak Pratama Bantul Yogyakarta sebesar 30.788 satuan.Variabel X yang merupakan koefisien regresi dari modernisasi sistem administrasi perpajakan sebesar 6,41 jika terjadi modernisasi sistem administrasi perpajakan di Kantor Pelayanan Pajak Pratama Bantul Yogyakarta sebesar satu (1) satuan, maka akan terjadi peningkatan kepatuhan wajib pajak sebesar 0,641 satuan dengan asumsi variabel lainnya tidak dilakukan atau sama dengan nol (0).

Berdasarkan tabel 4.10 di atas dapat dilihat bahwa nilai $\mathrm{t}$ hitung untuk variabel modernisasi sistem administrasi perpajakan terhadap kepatuhan wajib pajak (Y) sebesar 6,329 , berarti $\mathrm{t}$ hitung $>\mathrm{t}$ tabel $(6,329>$ 1,991), memiliki tingkat signifikansi 0.000 karena tingkat signifikansi lebih kecil dari 0.05 hal ini membuktikan bahwa H0 ditolak dan Ha diterima, ini menunjukkan bahwa variabel modernisasi sistem administrasiperpajakan berpengaruh positif signifikan terhadap Kepatuhan wajib pajak

\section{Koesisien Determinasi}

Koefisien determinasi digunakan untuk mengukur seberapa besar

Pengaruh modernisasi sistem adminitrasi perpajakan terhadap kepatuhan wajib pajak di KPP Pratama Bantul YogyakartaTabel 4.5 pada tabel tersebut diketahui bahwa Adjusted $R^{2}$ dari model diperoleh sebesar 0.145 yang berarti bahwa 14,5\% Kepatuhan wajib pajak di pengaruhi oleh modernisasi sistem administrasi perpajakan sedangkan sisanya $85.5 \%$ dipengaruhi oleh variabel lain di luar penelitian ini.

\section{Gambar 5}

Koefisien Determinasi

\begin{tabular}{|c|c|c|c|c|}
\hline Model & $\mathrm{R}$ & R Square & Adjusted R Square & $\begin{array}{l}\text { Std. Error of the } \\
\text { Estimate }\end{array}$ \\
\hline 1 & $.395^{\mathrm{a}}$ & .156 & .145 & 4.30568 \\
\hline \multicolumn{5}{|c|}{ a. Predictors: (Constant), Modernisasi } \\
\hline
\end{tabular}

\section{Pembahasan}

Berdasarkan hasil analisis ditemukan bahwa ada pengaruh penerapan modernisasi sistem dministrasi perpajakan di buktikan dengan nilai adjusted $R^{2}$ dari model diperoleh sebesar 0.145 yang berarti bahwa $14,5 \%$ Kepatuhan wajib pajak di pengaruhi oleh modernisasi sistem administrasi perpajakan Hasil uji hipotesis secara individu menunjukkan bahwa nilai $\mathrm{t}$ hitung untuk variabel modernisasi sistem administrasi perpajakan $(\mathrm{X})$ terhadap kepatuhan wajib pajak (Y) sebesar 6,329, berarti t hitung $>\mathrm{t}$ tabel $(6,329>1,991)$, memiliki tingkat signifikansi 0.000 karena tingkat signifikansi lebih kecil dari 0.05 hal inimenunjukkan bahwa variabel modernisasi sistem administrasi perpajakan berpengaruh positifsignifikan terhadap kepatuhan wajib pajak. Hasil penelitian ini mendukunghasil penelitian yang dilakukan Mangunsong 
(2009), Lasmi dan Misra (2012), dan Aprilina (2013).

\section{Kesimpulan}

Berdasarkan hasil analisis ditemukan bahwa ada pengaruh penerapan modernisasi sistem administrasi perpajakan yang terdiri dari dimensi struktur organisasi, prosedur organisasi, strategi organisasi dan budaya organisasi terhadap kepatuhan Wajib Pajak Kantor Pelayanan Pajak Pratama Bantul Yogyakarta.

Kemampuan persamaan regresi dalam penelitian ini untuk menjelaskan besarnya variasi yang terjadi pada variabel terikat adalah sebesar $14,5 \%$ sementara $85,5 \%$ dijelaskan oleh variabel lain yang tidak digunakan dalam persamaan regresi ini

\section{Impilikasi}

Beberapa implikasi dari penelitian ini adalah tinggi rendahnya anggapan wajib pajak terhadap proses reformasi dan modernisasi di kantor pajak berpengaruh terhadap tingkat kepatuhan mereka dan oleh karenanya aparatur perlu untuk tetap menjaga integritas dan nama baik mereka serta instansi untuk menciptakan wajib pajak yang patuh. Implikasi lain adalah fiskus harus lebih kuat dalam pengawasan karena temuan penelitian ini menunjukkan bahwa patuh dalam mendaftar sebagai wajib pajak tidaklah menjamin bahwa wajib pajak juga akan patuh dalam perhitungan, pembayaran dan pelaporan pajak.

\section{Keterbatasan}

Penelitian ini mempunyai beberapa keterbatasan, diantaranya penelitian ini terbatas hanya pada Wajib Pajak pajak yang ditemui oleh peneliti di KPP Pratama Bantul. Jumlah sampel dalam penelitian yang masih relatif sedikit, sulitnya mendapatkan karena faktor keengganan wajib pajak dan sensitivitas mereka terhadap masalah perpajakan. Kemudian penelitian ini hanya mengkaji pengaruh modernisasi sistem administrasi perpajakan terhadap tingkat kepatuhan Wajib Pajak tanpa mengukur tingkat kepatuhan sebelum dan sesudah diterapkannya modernisasi sistem administrasi perpajakan.

\section{Saran}

1. Direktorat Jenderal Pajak hendaknya terus melaksanakan dan mempertahankan

kekonsistensinannya untuk memodernisasikan administrasi perpajakan dalam rangka reformasi perpajakan secara berkesinambungan

2. Sebagai sistem dan sarana, penerapan modernisasi sistem administrasi perpajakan sangat tergantung pelaksanaanya, terutama bidang perpajakan yang sangat rentan akan kecurangan dan Korupsi. Semangat perubahan dalam modernisasi sistem administrasi perpajakan hendak nya dapat meningkatkan integritas dan moral pegawai pajak dan dapat mendorong komitmen Wajib pajak dalam pemenuhan kewajiban perpajakannya serta meningkatkan kepercayaan masyarakat terhadap perpajakan Indonesia

\section{DAFTAR PUSTAKA}

Apriliana. 2013. Pengaruh Penerapan Sistem Modernisasi Administrasi

Perpajakan Terhadap Kepatuhan Wajib Pajak ( Studi Empiris pada WPOP di Fakultas Ekonomi dan Bisnis Universitas Brawijaya Malang).Skripsi. Universitas Brawijaya. Malang

Azwar, Saifuddin. 2000. Reliabilitas dan Validitas. Yogyakarta. Pustaka Pelajar

Chandra, Mujilan. 2013. Modernisasi Sistem

Adminstrasi Perpajakan dan Kepatuhan Wajib Pajak. Jurnal Riset Manajemen dan Akuntansi. Vol.1, No 1

Bawazier, Fuad. 2011. Reformasi Pajak di Indonesia. Jurnal Legislasi Indonesia, Vol. 8, No. 1

Erly Suandi. 2008. Hukum Pajak. Edisi Empat. Jakarta. Salemba Empat

Fasmi, Misra.2010. Pengaruh Modernisasi Sistem Administrasi Perpajakan 
Terhadap Tingkat kepatuhan Pengusaha Kena Pajak DI Kantor Pelayanan Pajak (KPP) Pratama Padang.Jurnal Legislasi Indonesia Vol. 8, no 1

Gozali, Imam. 2006. Aplikasi Analisis Multivariate dengan Program SPSS. Semarang : Badan Penerbit Universitas Diponegoro

, 2011. Aplikasi Analisis Multivariate dengan Program IBM SPSS. Semarang. Badan Penerbit Universitas Diponegoro

Jogiyanto. 2008. Pedoman Survei Kuesioner. Yogyakarta. BPFE

Mangunsong, 2009. Pengaruh Penerapan Sistem Administrasi Perpajakan Modern Terhadap Kepatuhan Wajib Pajak. Skripsi. Fakultas Ekonomi Universitas Kristen Maranatha Bandung

Nurmantu, Safri. 2005. Pengantar Perpsajakan. Jakarta. Yayasan Obor

Pemerintah RI. 2007. Undang-Undang No. 28 tahun 2007 tentang Perubahan Ketiga atas Undang-undang No. 6 tahun 1983 tentang Ketentuan Umum dan Tata Cara Perpajakan. Jakarta

Pemerintah RI. Undang Undang No. 28 tahun 2007 Tentang Ketentuan Umum dan Tata Cara Perpajakan Pasal 1 angka 2. Jakarta

Pemerintah RI. 2009. Undang-Undang No. 42 tahun 2009 tentang Perubahan Ketiga atas Undang-Undang No. 8 tahun 1983 tentang Pajak Pertambahan Nilai Barang dan Jasa dan Pajak Penjualan atas Barang Mewah. Jakarta
Rahayu, Sri. 2009. Pengaruh Modernisasi Sistem Administrasi Perpajakan terhadap Kepatuhan Wajib Pajak Badan pada KPP Pratama Bandung. Jurnal Akuntansi. Vol. 1, No. 2: 119138

Santosa, Ashari.2005. Analisis Statistik dengan Microsoft Excel dan SPSS. Yogyakarta. Andi

Sekaran, Uma. 2006. Metode Penelitian Untuk Bisnis Edisi 4. Jakarta. Salemba Empat

Siahaan, Marihot Pahala. 2010. Hukum Pajak Elementer: Konsep Dasar Perpajakan Indonesia. Yogyakarta. Graha Ilmu

Sofyan, Taufan Marcus. 2005. Pengaruh Penerapan Sistem Administrasi Perpajakan Modern terhadap Kepatuhan Wajib Pajak pada Kantor Pelayanan Pajak di Lingkungan Kantor Wilayah Direktorat Jenderal Pajak Wajib Pajak Besar. Skripsi. Sekolah Tinggi Akuntansi Negara. Jakarta

Triwigati, Listaniai.2013. Pengaruh Penerapan Moderrnisasi Sistem Administrasi Perpajakan Terhadap Tingkat Kepatuhan Wajib Pajak (Studi Kasus atas Wajib Pajak Orang Pribadi pada Kantor Pelayanan Pajak Pratama Malang Utara).Jurnal Ilmiah Mahasiswa FEB 1.2

Rahayu, Sri. 2009. Pengaruh Modernisasi Sistem Administrasi Perpajakan terhadap Kepatuhan Wajib Pajak Badan pada KPP Pratama Bandung. Jurnal Akuntansi. Vol. 1, No. 2: 119138 